\title{
Identifikasi Tumbuhan Famili Solanaceae Yang Terdapat Di Kecamatan Tugumulyo
}

\author{
Yuni Krisnawati ${ }^{1}$, Yuli Febrianti ${ }^{1}$ \\ ${ }^{1}$ Jurusan Pendidikan Matematika dan Pengetahuan Alam, STKIP-PGRI Lubuklinggau \\ Jl. Mayor TohaTaba Pingin Kel. Air Kuti Kec. Lubuklinggau Timur I, Kota Lubuklinggau 31626 \\ Indonesia \\ e-mail: yuli_febri.anti16@yahoo.co.id, yunikris_89@yahoo.co.id
}

\begin{abstract}
Abstrak
Tujuan dari penelitian ini adalah untuk mengetahui jenis-jenis tumbuhan famili Solanaceae di Kecamatan Tugumulyo. Adapun jenis penelitian ini adalah deskriptif eksplorasi. Teknik pengambilan data dengan observasi dan wawancara. Cara kerja yang dilakukan yaitu observasi lapangan dan observasi laboratorium. Data yang diperoleh dari penelitian dianalisis secara deskriptif kualitatif, yaitu dengan mencocokkan ciri-ciri sampel yang telah ditemukan dengan buku acuan yaitu buku karangan Gembong Tjitrosoepomo tahun 2010 dan Van Steenis., et al tahun 2008. Hasil penelitian didapat 5 genus dan 11 species yaitu Genus Solanum diperoleh 6 species: Solanum indicum (Terung peuheur), Solanum lycopersicum (Tomat), Solanum melongena (Terung), Solanum nigrum (Leunca) dan Solanum torvum (Takokak), Solanum tuberosum (Kentang). Kemudian genus Capsicum diperoleh 2 species: Capsicum annum (Cabe merah) dan Capsicum frutescens (Cabe rawit), genus Datura diperoleh 1 species: Datura metel (Kecubung), genus Brugmansia diperoleh 1 species: Cestrum nocturnum (Harum Dalu), dan genus Physalis diperoleh 1 species: Physalis angulata (Ceplukan).
\end{abstract}

Kata Kunci-Identifikasi, Solanaceae, Tugumulyo

\begin{abstract}
The purpose of this study was to determine the types of Solanaceae families in Tugumulyo Subdistrict. The type of this research is descriptive exploration. Data collection techniques by observation and interview. The method of work is field observations and laboratory observations. The data obtained from the study were analyzed qualitatively qualitative, namely by matching the characteristics of the samples that have been found with the reference book namely the book written by Gembong Tjitrosoepomo in 2010 and Van Steenis., et al in 2008. The results obtained 5 genera and 11 species namely Genus Solanum obtained 6 species: Solanum indicum (Terung peuheur), Solanum lycopersicum (Tomat), Solanum melongena (Terung), Solanum nigrum (Leunca) and Solanum torvum (Takokak), Solanum tuberosum (Kentang). Then the genus Capsicum obtained 2 species: Capsicum annum (Cabe merah) and Capsicum frutescens (Cabe rawit), genus Datura obtained 1 species: Datura metel (Kecubung), genus Brugmansia obtained 1 species: Cestrum nocturnum (Harum Dalu), and the genus Physalis obtained 1 species: Physalis angulata (Ceplukan).
\end{abstract}

Keywords: Identification, Solanaceae, Tugumulyo.

\section{PENDAHULUAN}

Solanaceae (suku terung-terungan) merupakan salah satu suku tumbuhan berbunga, herba atau perdu, dan kadang-kadang pohon. Suku Solanaceae terbagi kurang lebih 80 genus dan seluruhnya mencakup sekitar 1.700 jenis, yang tersebar di daerah-daerah iklim panas sampai daerah-daerah iklim sedang. Semua anggota famili Soalanaceae memiliki trikoma pada daun kelopaknya dan variasi bentuk trikomanya yaitu bentuk gelembung, sabit, bintang dan bejumbai (Tjitrosoepomo, 2007). 
Famili Solanaceae adalah salah satu famili terpenting dalam hal memenuhi kebutuhan manusia. Famili ini tidak hanya terdiri dari sayur-sayuran yang penting dan buah-buahan seperti kentang, tomat, terung, paprika, cabai, paprika hijau dan merah, tetapi juga digunakan sebagai tanaman hias contohnya petunia, dan juga untuk pengobatan, narkotika, obat bius dan bahkan beracun (Setshogo, 2015). Ada 8 genus dari famili Solanaceae yang berbentuk pohon yaitu Solanum, Lycianthes, Cestrum, Nolana, Physalis, Lycium, Nicotiana, dan Brunfelsia memiliki lebih dari $60 \%$ jenis (Yadav et al., 2016).

Kecamatan Tugumulyo sebagai kawasan andalan dari Kabupaten Musi Rawas (Pemkab Mura, 2010) memiliki iklim tropis basah, suhu minimum $19.6^{\circ} \mathrm{C}, \mathrm{pH}$ tanah antara 4.5-6.0, dan curah hujan 2.285 per tahun yang menjadikan kawasan ini memiliki sektor unggulan, meliputi: peternakan, perikanan, dan pertanian (padi). Hal ini sesuai dengan pendapat Sunarjono (2007) bahwa tumbuhan solanaceae secara umum memerlukan tanah yang gembur, sedikit menggandung pasir, $\mathrm{pH}$ tanahnya 5-6, ditanam di dataran rendah sampai dataran tinggi dengan suhu udara sekitar $20^{\circ} \mathrm{C}$ serta memerlukan tanah yang beriklim basah (curah hujan 1000-2000 mm per tahun). Dengan demikian dapat disimpulkan bahwa akan ditemukan beberapa jenis tumbuhan famili Solanaceae di Kecamatan Tugumulyo.

Berdasarkan observasi awal, banyak ditemukan berbagai jenis tumbuhan famili Solanaceae, namun hanya beberapa yang dikenal baik dan dikonsumsi oleh masyarakat. Selain itu tumbuhan dari famili Solanaceae yang lainnya belum mendapatkan perhatian dari masyarakat untuk dikembangkan atau dibudidayakan padahal mempunyai nilai ekonomis tinggi. Penelitian tentang identifikasi tumbuhan famili solanaceae di Kecamatan Tugumulyo juga belum pernah dilakukan sehingga belum ada data jenis-jenis tumbuhan famili Solanaceae yang dapat dan tidak dapat dikonsumsi.

\section{METODE PENELITIAN}

\section{A. Jenis Penelitian}

Jenis penelitian yang digunakan yaitu deskriptif eksploratif. Eksploratif dilakukan dengan cara jelajah bebas di sepuluh Desa di
Kecamatan Tugumulyo. Tujuan dari jelajah bebas yaitu untuk menggambarkan sesuatu yang dilakukan dengan studi langsung ke lapangan mengenai objek yang diteliti supaya memperoleh pengetahuan yang lebih banyak tentang suatu keadaan.

\section{B. Waktu dan Tempat Penelitian}

Penelitian ini dimulai dari bulan Januari sampai bulan Maret 2017. Tempat penelitian yang terdiri dari sepuluh Desa yaitu Desa Dwijaya, Desa Mataram, Desa Sidoharjo, Desa Srikaton, Desa Tambahasri, Desa Tegal Rejo, Desa Trikoyo, Desa Widodo, Desa Wonorejo, dan Desa Wukirsari Kecamatan Tugumulyo.

\section{Bahan dan Alat}

Alat yang digunakan dalam penelitian ini adalah kantong plastik besar, tali rafia, kertas label, pisau pemotong, alat-alat tulis, kertas koran, papan triplek, album foto, dan kamera photo, sedangkan bahan yang digunakan dalam penelitian ini adalah alkohol $70 \%$.

\section{Cara Kerja}

1) Oservasi lapangan

Observasi lapangan dilakukan dengan cara menjelajahi lokasi penelitian dan melakukan wawancara terhadap masyarakat (informan) setempat tentang pemanfaatan tumbuhan famili Solanaceae yang terdapat di Kecamatan Tugumulyo Kabupaten Musi Rawas.

2) Observasi Laboratorium

a) Pembuatan Herbarium

Setelah sampel dikumpulkan, selanjutnya sampel dibuat herbarium yaitu herbarium kering yang dapat digunakan sebagai bahan pengamatan mengenai morfologi dari tumbuhan famili Solanaceae dan dapat juga berguna sebagai bukti ilmiah yang dapat disimpan dalam waktu yang cukup lama.

Langkah-langkah pembuatan herbarium menurut (Tjitrosoepomo, 2009:195) adalah sebagai berikut:

i) Sampel yang dikumpulkan dari lapangan dibersihkan terlebih dahulu dengan air dengan cara dicuci.

ii) Sampel yang telah terkumpul dan telah diberi label gantung, kemudian direndam dengan alkohol, kira-kira 10 menit. 
iii) Spesimen/sampel diangkat kemudian diletakkan di atas koran satu persatu dan disusun sedemikian rupa.

iv) Setelah seluruh spesimen/sampel dimasukkan ke dalam kertas koran, spesimen dijepit dengan papan triplek dan diikat dengan menggunakan tali rapia, bagian atas dan bagian bawahnya yang bertujuan agar spesimen tidak terlipat atau bergeser selama pengepresan.

v) Setelah itu spesimen disimpan dalam jangka waktu 3-4 hari.

vi) Setelah beberapa hari kemudian, spesimen dibuka dan diangin-anginkan untuk memperoleh hasil yang lebih sempurna.

vii) Setelah spesimen diangin-anginkan, spesimen/sampel tadi dimasukkan ke dalam album dan diberi label yang berisi datadata famili "Solanaceae" seperti data taksonomi (nama spesies), nama kolektor, lokasi dan tanggal koleksi.

viii) Spesimen siap dijadikan herbarium.

b) Identifikasi setiap sampel

Pengidentifikasi dengan menggunakan buku panduan karangan Gembong Tjitrosoepomo tahun 2010 dan Van Steenis., et al tahun 2008.

\section{E. Teknik Pengumpulan Data}

Teknik Pengumpulan data dalam penelitian ini melalui tahap-tahap yaitu tahap observasi mengenai jenis tumbuhan famili Solanceae yang terdapat di empat desa yang sudah terpilih menjadi tempat penelitian. Data observasi digunakan untuk menggali informasi tentang berapa banyak jenis-jenis tumbuhan famili Solanaceae yang terdapat di sepuluh desa dengan menjelajahi lokasi penelitian. Selanjutnya tahap wawancara dilakukan dengan teknik wawancara semi struktural dengan mengajukan pertanyaan yang telah disiapkan. Menurut Yusuf (2014:377) mengemukakan bahwa teknik wawancara semi struktural dilakukan dengan menyusun rencana yang mantap terlebih dahulu, tetapi tidak menggunakan format dan urutan yang baku. Wawancara dilakukan untuk mengetahui data lisan dari masyarakat (informan) tentang pemanfaatan tumbuhan famili Solanaceae yang digunakan masyarakat sebagai tanaman pangan, tumbuhan obat, dan tanaman hias. Masyarakat yang diwawancarai dipilih menjadi informan umum dengan teknik snowball sampling. Menurut Sugiyono (2012:219) menyatakan bahwa teknik snowball sampling adalah teknik pengambilan sampel sumber data yang pada awal jumlahnya sedikit, lama-lama menjadi besar. Hal ini dilakukan karena dari jumlah sumber data yang sedikit itu tersebut belum mampu memberikan data yang memuaskan.

\section{F. Anaslis Data}

Semua data dianalisis secara deskriptif kualitatif dari hasil wawancara kepada masyarakat (informan) dengan mencocokkan manfaat tumbuhan famili solanaceae di lokasi tumbuhnya famili solanaceae dari sepuluh Desa di Kecamatan Tugumulyo Kabupaten Musi Rawas berdasarkan buku /jurnal/artikel.

\section{HASIL DAN PEMBAHASAN}

Kecamatan Tugumulyo terdiri 18 Desa yaitu: Desa Dwijaya, Desa Kali Bening, Desa Mataram, Desa Nawangsasi, Desa Ngadirejo, Desa Sidoharjo, Desa Sitiharjo, Desa Srikaton, Desa Sukomulyo, Desa Surodadi, Desa Tambahasri, Desa Tegal Rejo, Desa Trikoyo, Desa Triwikaton, Desa Widodo, Desa Wonokerto, Desa Wonorejo, dan Desa Wukirsari.

Adapun lokasi yang dijadikan penelitian adalah Desa Dwijaya, Desa Mataram, Desa Sidoharjo, Desa Srikaton, Desa Tambahasri, Desa Tegal Rejo, Desa Trikoyo, Desa Widodo, Desa Wonorejo, dan Desa Wukirsari Kecamatan Tugumulyo Kabupaten Musi Rawas beriklim tropis basah, suhu minimum $19.6^{\circ} \mathrm{C}, \mathrm{pH}$ tanah antara 4.5-6.0, dan curah hujan 2.285 per tahun. Batasbatas administrasi Kecamatan Tugumulyo yaitu Sebelah Utara berbatasan dengan Kecamatan Purwodadi. Sebelah Barat berbatasan dengan Kecamatan Muara Beliti. Sebelah Timur berbatasan dengan Kecamatan Sumber Harta dan Sebelah Selatan berbatasan dengan Kota Lubuklinggau.

Secara Administrasi Kecamatan Tugumulyo berjarak $\pm 21 \mathrm{~km}$ dari Kabupaten Musi Rawas dan berjarak $\pm 27 \mathrm{~km}$ dari kota Lubuklinggau ke lokasi penelitian. Keseluruhan Desa Dwijaya, Desa Mataram, Desa Sidoharjo, Desa Srikaton, Desa 
Tambahasri, Desa Tegal Rejo, Desa Trikoyo, Desa Widodo, Desa Wonorejo, Desa Wukirsari, meliputi: areal perkebunan, persawahan, ladang, peternakan, perikanan, irigasi dan non irigasi.
Setelah diadakan penelitian ditemukan family Solanaceae yang terdiri dari 5 genus dan 11 species. Data secara lengkap dapat dilihat pada tabel berikut ini:

Tabel 1.

Hasil identifikasi famili solanaceae

\begin{tabular}{llll}
\hline \hline \multicolumn{1}{c}{ Genus } & \multicolumn{1}{c}{ Nama Species } & \multicolumn{1}{c}{ Nama Daerah } & Nama Indonesia \\
\hline \multirow{2}{*}{ Capsicum } & Capsicum annum & Cabe merah & Cabe merah \\
Datura & Capsicum frutescens & Cabe rawit & Cabe rawit \\
Cestrum & Datura metel & Kecubung putih & Kecubung \\
Physalis & Cestrum nocturnum & Arum dalu & Harum Dalu \\
& Physalis angulata & Seletup, ceplukan & Ceplukan \\
& Solanum indicum & Terong bulat, & Terung peuheur \\
& Solanum lycopersicum & Tomat & Tomat \\
\multirow{5}{*}{ Solanum } & Solanum melongena & Terong & Terong \\
& Solanum nigrum & Lumai & Leunca \\
& Solanum torvum & Cepokak, Cempokak & Takokak \\
& Solanum tuberosum & Kentang pleci & Kentang \\
\hline \hline
\end{tabular}

Tabel 2.

Hasil identifikasi famili solanaceae yang terdapat di setiap Desa

\begin{tabular}{|c|c|c|c|c|c|c|c|c|c|c|}
\hline & & & & & ams & De & & & & \\
\hline & D & M & $S$ & $S$ & $\mathrm{~T}$ & $\mathrm{~T}$ & $\mathrm{~T}$ & W & W & $\mathrm{W}$ \\
\hline & W & $\mathrm{a}$ & $\mathrm{i}$ & $r$ & $\mathrm{a}$ & e & $\mathrm{r}$ & $\mathrm{i}$ & o & $\mathrm{u}$ \\
\hline & $\mathrm{i}$ & $\mathrm{t}$ & d & $\mathrm{i}$ & $\mathrm{m}$ & $\mathrm{g}$ & $\mathrm{i}$ & d & $\mathrm{n}$ & $\mathrm{k}$ \\
\hline & $\mathrm{j}$ & $\mathrm{a}$ & o & $\mathrm{k}$ & $\mathrm{b}$ & $\mathrm{a}$ & $\mathrm{k}$ & o & o & $\mathrm{i}$ \\
\hline Species & a & $\mathrm{r}$ & h & a & a & 1 & o & d & $\mathrm{r}$ & $r$ \\
\hline & $\mathrm{y}$ & $\mathrm{a}$ & $\mathrm{a}$ & $\mathrm{t}$ & $\mathrm{h}$ & $\mathrm{R}$ & $\mathrm{y}$ & o & $\mathrm{e}$ & $\mathrm{s}$ \\
\hline & a & $\mathrm{m}$ & $\mathrm{r}$ & o & a & $\mathrm{e}$ & o & & $\mathrm{j}$ & $\mathrm{a}$ \\
\hline & & & $\mathrm{j}$ & $\mathrm{n}$ & $\mathrm{s}$ & $\mathrm{j}$ & & & o & $\mathrm{r}$ \\
\hline & & & o & & $\mathrm{r}$ & o & & & & $\mathrm{i}$ \\
\hline & & & & & $\mathrm{i}$ & & & & & \\
\hline Capsicum аппит & + & + & + & + & + & + & + & + & + & + \\
\hline Capsicum frutescens & + & + & + & + & + & + & + & + & + & + \\
\hline Cestrum nocturnum & + & - & - & - & - & - & - & - & - & - \\
\hline Datura metel & + & + & + & + & + & + & - & - & + & - \\
\hline Physalis angulata & + & + & + & + & + & + & + & + & + & + \\
\hline Solanum indicum & + & + & + & + & + & + & + & + & + & + \\
\hline Solanum lycopersicum & + & + & + & + & + & + & + & + & + & + \\
\hline Solanum melongena & + & - & - & + & + & - & + & + & + & + \\
\hline Solanum nigrum & - & - & - & + & - & + & + & - & - & - \\
\hline Solanum torvum & + & + & + & + & + & + & + & + & + & + \\
\hline Solanum tuberosum & + & - & + & - & - & - & - & + & - & + \\
\hline Jumlah species & $\begin{array}{l}1 \\
0\end{array}$ & 7 & 8 & 9 & 8 & 8 & 8 & 8 & 9 & 8 \\
\hline
\end{tabular}

Keterangan:

$\begin{array}{ll}\text { Ditemukan } & =+ \\ \text { Tidak ditemukan } & =-\end{array}$

Tabel 3.

Hasil identifikasi famili solanaceae dan manat erdasarkan wawancara, buku, jurnal, dan artikel

\begin{tabular}{|c|c|c|c|c|c|}
\hline Nama Lokal & Nama Ilmiah & $\begin{array}{l}\text { Ciri-ciri } \\
\text { Morfologi }\end{array}$ & $\begin{array}{c}\text { Bagian } \\
\text { Tumbuhan yang } \\
\text { digunakan }\end{array}$ & $\begin{array}{c}\text { Manfaat } \\
\text { Berdasarkan } \\
\text { wawancara }\end{array}$ & $\begin{array}{c}\text { Manfaat Berdasarkan } \\
\text { Buku/Jurnal/Artikel }\end{array}$ \\
\hline Cabe & Capsicum annum & $\begin{array}{c}\text { Ujung daun } \\
\text { runcing, Tepi } \\
\text { daun rata. Bunga } \\
\text { berwarna putih. } \\
\text { Buahnya } \\
\text { berwarna hijau } \\
\text { jika masih muda }\end{array}$ & Buah & $\begin{array}{l}\text { Antioksidan, sakit } \\
\text { perut, flu, sariawan, } \\
\text { rematik, sebagai } \\
\text { penambah napsu } \\
\text { makan, bumbu } \\
\text { masak }\end{array}$ & $\begin{array}{l}\text { Antifungai (De Lucca., } \\
\text { et al, 2006:42 dan } \\
\text { Soumya and Bindu, } \\
\text { 2012:750), penurunan } \\
\text { kadar gula darah } \\
\text { (Tundis., } \text { et al, } \\
\text { 2011:269), }\end{array}$ \\
\hline
\end{tabular}




\begin{tabular}{|c|c|c|c|c|c|}
\hline Nama Lokal & Nama Ilmiah & $\begin{array}{l}\text { Ciri-ciri } \\
\text { Morfologi }\end{array}$ & $\begin{array}{c}\text { Bagian } \\
\text { Tumbuhan yang } \\
\text { digunakan } \\
\end{array}$ & $\begin{array}{c}\text { Manfaat } \\
\text { Berdasarkan } \\
\text { wawancara } \\
\end{array}$ & $\begin{array}{c}\text { Manfaat Berdasarkan } \\
\text { Buku/Jurnal/Artikel }\end{array}$ \\
\hline & & $\begin{array}{c}\text { dan berwarna } \\
\text { merah jika sudah } \\
\text { tua }\end{array}$ & & & $\begin{array}{c}\text { menghambat } \\
\text { pertumbuhan bakteri } \\
\text { Streptococcus mutans } \\
\text { (Santos., } \text { et al, } \\
\text { 2007:356), antioksidan } \\
\text { (Lei Chen., et al, } \\
\text { 2012:721).. }\end{array}$ \\
\hline Cabe Rawit & $\begin{array}{l}\text { Capsicum } \\
\text { futesrcens }\end{array}$ & $\begin{array}{l}\text { Daun bualat } \\
\text { telur, tepi daun } \\
\text { rata, ujung daun } \\
\text { meruncing. } \\
\text { Bunga berwarna } \\
\text { putih. Buah nya } \\
\text { berwarna hijau } \\
\text { jika masih muda } \\
\text { dan berwarna } \\
\text { merah jika sudah } \\
\text { tuh serta rasa } \\
\text { buah sangat } \\
\text { pedas }\end{array}$ & Buah & Rematik & $\begin{array}{c}\text { Luka, rematik } \\
\text { (Sumpena, 2013:9) }\end{array}$ \\
\hline Arum Dalu & Cestrum nocturnum & 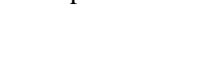 & Daun & Obat Luka & $\begin{array}{c}\text { Obat Luka (Sotyati, } \\
2016)\end{array}$ \\
\hline Kecubung & Datura metel & $\begin{array}{c}\text { Daun bulat telur. } \\
\text { Bunga } \\
\text { menyerupai } \\
\text { terompet } \\
\text { berwarna putih } \\
\text { atau lembayung. } \\
\text { Buah kecubung } \\
\text { bagian luarnya } \\
\text { dihiasi duri-duri } \\
\text { dan dalamnya } \\
\text { berisi biji-biji } \\
\text { kecil berwarna } \\
\text { kuning } \\
\text { kecoklatan }\end{array}$ & Daun & $\begin{array}{l}\text { Pegal linu, demam, } \\
\text { obat cacingan, perut } \\
\text { kembung, bengkak. }\end{array}$ & $\begin{array}{l}\text { Asma, rematik, sakit } \\
\text { pinggang, pegl linu, } \\
\text { bisul, eksim (Putra, } \\
\text { 2016). }\end{array}$ \\
\hline Ceplukan & Physalis angulata & $\begin{array}{l}\text { Tumbuhan liar } \\
\text { berupa semak. } \\
\text { Bunga berwarna } \\
\text { kuning. Buah } \\
\text { berbentuk bulat, } \\
\text { berwarna } \\
\text { kekuningan bila } \\
\text { masih muda, bila } \\
\text { sudah tua } \\
\text { berwarna } \\
\text { kekuningan atau } \\
\text { cokelat, rasa } \\
\text { asam manis. } \\
\text { Buah muda } \\
\text { dilindngi } \\
\text { cangkap } \\
\text { Batang dan daun } \\
\text { berbulu, pangkal } \\
\text { daun berlekuk, } \\
\text { ujung daun } \\
\text { meruncing. }\end{array}$ & $\begin{array}{l}\text { Daun, batang, } \\
\text { buah, bunga, akar }\end{array}$ & $\begin{array}{l}\text { Korengan, cacar, } \\
\text { gatal-gatal, luka, } \\
\text { hipertensi, demam, } \\
\text { pusing, diabetes, } \\
\text { asam urat, sakit } \\
\text { perut, flu, sakit } \\
\text { tenggorokan, sakit } \\
\text { kuning, malaria, } \\
\text { batuk rejan, } \\
\text { bronchitis, gondong, } \\
\text { bisul, borok, } \\
\text { diabetes, paru-paru, } \\
\text { ayan }\end{array}$ & $\begin{array}{l}\text { Batuk, flu, sakit } \\
\text { gondong, kencing } \\
\text { manis, epilepsi, } \\
\text { pembengkakan prostat } \\
\text { (Faiha, 2015). } \\
\text { Korengan, cacar, } \\
\text { hipertiroid, } \\
\text { diabetes,darah tinggi, } \\
\text { panas dalam (Permadi, } \\
\text { 2009) }\end{array}$ \\
\hline Terong Bulat & Solanum indicum & $\begin{array}{c}\text { Bunga berwarna } \\
\text { putih keunguan. } \\
\text { Buah berwarna } \\
\text { hijau jika masih } \\
\text { muda dan } \\
\text { berwarna orange } \\
\text { bila sudah tua }\end{array}$ & Biji & jerawat, radang usus & $\begin{array}{l}\text { Radang usus, hepatitis } \\
\text { (Hariana, 2008:145) }\end{array}$ \\
\hline
\end{tabular}




\begin{tabular}{|c|c|c|c|c|c|}
\hline Nama Lokal & Nama Ilmiah & $\begin{array}{l}\text { Ciri-ciri } \\
\text { Morfologi }\end{array}$ & $\begin{array}{c}\text { Bagian } \\
\text { Tumbuhan yang } \\
\text { digunakan }\end{array}$ & $\begin{array}{c}\text { Manfaat } \\
\text { Berdasarkan } \\
\text { wawancara }\end{array}$ & $\begin{array}{c}\text { Manfaat Berdasarkan } \\
\text { Buku/Jurnal/Artikel }\end{array}$ \\
\hline Tomat & $\begin{array}{c}\text { Solanum } \\
\text { lycopersicum }\end{array}$ & $\begin{array}{c}\text { Batang berbentuk } \\
\text { bulat berwarna } \\
\text { hijau keputihan } \\
\text { serta batang dan } \\
\text { daunnya berbulu } \\
\text { halus. Daun } \\
\text { majemuk } \\
\text { menyirip dengan } \\
\text { panjang 10-40 } \\
\text { cm, tepi daun } \\
\text { bergerigi. Bunga } \\
\text { Berwarna kuning } \\
\text { Batang dan daun }\end{array}$ & Buah & $\begin{array}{c}\text { Sariawan, } \\
\text { menghaluskan kulit, } \\
\text { Kesehatan mata, } \\
\text { luka bakar }\end{array}$ & $\begin{array}{c}\text { Luka bakar, sariawan, } \\
\text { diabetes (Hariana, } \\
\text { 2008: 146) }\end{array}$ \\
\hline Terong & Solanum melongena & $\begin{array}{l}\text { yang berbulu dan } \\
\text { biasanya batang } \\
\text { berduri. Pangkal } \\
\text { daun berlekuk, } \\
\text { ujung daun } \\
\text { runcing. Bunga } \\
\text { berwarna antara } \\
\text { putih hingga } \\
\text { jingga dan Buah } \\
\text { berwarna ungu }\end{array}$ & Buah & $\begin{array}{c}\text { Hipertensi, } \\
\text { mencegah kanker, } \\
\text { jantung, paru-paru }\end{array}$ & $\begin{array}{c}\text { Jantung, menurunkan } \\
\text { berat badan, membantu } \\
\text { pencernaan, } \\
\text { mengontrol kadar gula } \\
\text { darah, kesehatan kulit, } \\
\text { melembabkan kulit } \\
\text { kepala, mencegah } \\
\text { diabetes (Rediana, } \\
\text { 2016). }\end{array}$ \\
\hline Cepokak & Solanum torvum & $\begin{array}{c}\text { Batang bulat, } \\
\text { berkayu, } \\
\text { bercabang, } \\
\text { berduri jarang. } \\
\text { Daun tunggal } \\
\text { berbentuk bulat } \\
\text { telur. Ibu tulang } \\
\text { daun berduri. } \\
\text { Bunga majemuk } \\
\text { berbentuk } \\
\text { bintang, } \\
\text { berwarna putih. } \\
\text { Buah buni bulat, } \\
\text { apabila masih } \\
\text { muda berwarna } \\
\text { hijau setelah tua } \\
\text { berwarna jingga. }\end{array}$ & Buah & $\begin{array}{l}\text { Vertigo, mata } \\
\text { bening, mata rabun, } \\
\text { hipertensi, diabetes, } \\
\text { benjolan di tubuh }\end{array}$ & $\begin{array}{c}\text { Mengobati bengkak, } \\
\text { batuk kronis, nyeri } \\
\text { jantung, hipertensi } \\
\text { (Sirait, 2009:12). } \\
\text { Mencegah Mata Mins, } \\
\text { melancarkan } \\
\text { peredaran darah } \\
\text { Hariana, 2008:93) }\end{array}$ \\
\hline Lumai & Solanum nigrum & $\begin{array}{l}\text { Batang berwarna } \\
\text { hijau, berdaun } \\
\text { tunggal dan } \\
\text { lonjong. Pangkal } \\
\text { dan ujung daun } \\
\text { meruncing } \\
\text { dengan tepi rata. } \\
\text { Buah berwarna } \\
\text { hijau kalau masih } \\
\text { muda dan } \\
\text { berwarna hitam } \\
\text { mengkilap bila } \\
\text { sudah tua }\end{array}$ & Daun dan Buah & Mencegah kelenjar & $\begin{array}{c}\text { Antikanker, mencegah } \\
\text { dan mengurangi } \\
\text { peradangan, } \\
\text { menurunkan demam } \\
\text { (penurun panas), } \\
\text { mengurangi rasa sakit, } \\
\text { melancarkan sirkulasi } \\
\text { darah (mencegah } \\
\text { jipertensi), meredakan } \\
\text { batuk yang disertai } \\
\text { dahak dan melegakan } \\
\text { nafas, antibiotik, } \\
\text { antimikroba, } \\
\text { menghilangkan gatal } \\
\text { (Anti-pruritus), dan } \\
\text { emiliki aktifitas anti- } \\
\text { ulserogenik yang } \\
\text { terhubung dengan } \\
\text { lambung, sistem saraf } \\
\text { pusat, dan sebagai } \\
\text { agen anti-neoplastik. } \\
\text { Hal ini juga memiliki } \\
\text { peran sebagai } \\
\text { sitoprotektif yang } \\
\text { melawan kerusakan }\end{array}$ \\
\hline
\end{tabular}




\begin{tabular}{|c|c|c|c|c|c|}
\hline Nama Lokal & Nama Ilmiah & $\begin{array}{l}\text { Ciri-ciri } \\
\text { Morfologi }\end{array}$ & $\begin{array}{c}\text { Bagian } \\
\text { Tumbuhan yang } \\
\text { digunakan } \\
\end{array}$ & $\begin{array}{c}\text { Manfaat } \\
\text { Berdasarkan } \\
\text { wawancara }\end{array}$ & $\begin{array}{c}\text { Manfaat Berdasarkan } \\
\text { Buku/Jurnal/Artikel }\end{array}$ \\
\hline Kentang & Solanum tuberosum & $\begin{array}{l}\text { Berbatang basah. } \\
\text { Daun berbentuk } \\
\text { bulat telur } \\
\text { berseling } \\
\text { menyirip ganjil. } \\
\text { Bunga berwarna } \\
\text { ungu. Tidak ada } \\
\text { Serbuk Sari. } \\
\text { Buah Buni. Umbi } \\
\text { batang pada } \\
\text { stolon }\end{array}$ & Umbi & $\begin{array}{c}\text { Jerawat, Bengkak } \\
\text { pada mata }\end{array}$ & $\begin{array}{c}\text { pada ginjal } \\
\text { (Purwaningsih, 2016). } \\
\text { Mencegah kanker, } \\
\text { menurunkan kadar } \\
\text { kolesterol, mengurangi } \\
\text { resiko batu ginjal, } \\
\text { menyehatkan tulang, } \\
\text { menyehatkan jantung, } \\
\text { kesehatan otak dan } \\
\text { saraf, mengatasi } \\
\text { jerawat, mengatasi } \\
\text { bengkak pada mata } \\
\text { (Kurniawan, 2017). }\end{array}$ \\
\hline
\end{tabular}

Berdasarkan hasil penelitian di Kecamatan Tugumulyo Kabupaten Musi Rawas, diperoleh 11 species dan termasuk ke dalam 5 genus, yaitu: Genus Solanum diperoleh 6 species: Solanum indicum, Solanum lycopersicum, Solanum melongena, Solanum nigrum, dan Solanum torvum. Kemudian genus Capsicum diperoleh 2 species: Capsicum annum dan Capsicum frutescens, genus Datura diperoleh 1 species: Datura metel, genus Cestrum diperoleh 1 species: Cestrum nocturnum, dan genus Physalis diperoleh 1 species: Physalis angulata.

Berdasarkan tabel 1 dapat terlihat bahwa dari 5 genus yang ditemukan, genus Solanum memiliki species yang paling banyak yang terdiri dari 6 species yaitu: Species Solanum indicum, Solanum lycopersicum, Solanum nigrum, Solanum torvum, dan Solanum tuberosum merupakan tanaman sayuran yang memiliki banyak manfaat antara lain untuk dimasak dan dijadikan lalapan oleh karena itu, banyak digemari oleh masyarakat di sekitar lokasi penelitian. Hal ini sesuai dengan Knapp, dkk., 2004 dan Suyoga, dkk., 2016 yaitu Solanum lycopersicum yang menjadi bagian utama bahan pangan untuk manusia di berbagai belahan dunia. Beberapa sayuran lainnya, Solanum indicum dan Solanum torvum juga menjadi bagian menu makanan.

Berdasarkan tabel 2 dapat terlihat bahwa Species Cestrum nocturnum merupakan species yang sedikit ditemukan di lokasi penelitian. Tumbuhan Cestrum nocturnum termasuk jenis tanaman hias oleh masyarakat di sekitar lokasi penelitian dan tanaman tersebut hanya ditanam di daerah pekarangan rumah maupun di halaman belakang rumah yang tanahnya subur. Hal ini sesuai dengan
Steenis., et al (2008:348), Cestrum nocturnum merupakan tanaman hias yang hidup di dataran tinggi 1-1.500 $\mathrm{m} \mathrm{dpl}$.

Species Capsicum annum ditemukan di sepuluh desa di Kecamatan Tugumulyo Kabupaten Musi Rawas. Hal ini karena pada umumnya masyarakat kesepuluh desa tersebut sudah membudidayakan species ini dengan pengaturan dan perawatan secara teratur, mulai dari pemilihan varietas sampai pascapanen, sehingga hasil yang didapat juga memuaskan. Selain itu Capsicum annum digunakan sebagai bumbu masak, sariawan, flu, antioksidan, dan penambah napsu makan. Hasil penelitian De Lucca., et al, (2006:42) dan Soumya and Bindu, (2012:750) yaitu Capsicum annum sebagai antifungai. Selanjutnya Tundis., et al, (2011:269) sebagai penurunan kadar gula darah. Selanjutnya Santos., et al, (2007:356) dapat menghambat pertumbuhan bakteri Streptococcus mutans, dan antioksidan (Lei Chen., et al, 2012: 721).

Species Capsicum frutescens (Cabe rawit) ditemukan di sepuluh desa. Hal ini karena species ini sudah pada tempatnya yaitu di daerah tegalan dan spesies ini sesuai dengan iklim kering atau penghujan pada kesepuluh desa tersebut. Selain itu Capsicum frutescens berkhasiat untuk menyembuhkan rematik dan luka. Menurut Sumpena (2013:9), Capsicum frutescens dapat menyembuhkan luka dan rematik.

Species Datura metel (kecubung) tidak ditemukan di Desa Trikoyo, Desa Widodo, dan Desa Wukir Sari karena kurang tertariknya masyarakat ketiga desa tersebut untuk membudidayakan species ini, karena memiliki duri dan racun yang berbahaya. Datura metel mungkin beracun jika ter- 
telan dalam jumlah kecil, gejala yang dinyatakan sebagai kulit memerah, sakit kepala, halusinasi, dan mungkin kejang atau bahkan koma. Unsurunsur beracun utama adalah alkaloid tropane. Sengaja (atau sengaja) menelan bahkan daun tunggal dapat menyebabkan efek samping berat, sedangkan ditemukan di Desa Dwijaya, Desa Mataram, Desa Sidoharjo, Desa Srikaton, Desa Tambahasri, Desa Tegal Rejo dan Desa Wonorejo. Hal ini karena masyarakat kedua desa tersebut sudah membudidayakan tanaman ini yaitu di daerah sekitar pekarangan rumah, sebagai tanaman hias dan tanaman ini juga ditemukan secara liar. $D a-$ tura metel (Kecubung) dapat tumbuh liar di ladang, kecubung juga sering ditanam di kebun atau ditanam sebagai tumbuhan hias di pekarangan. Hal ini sesuai dengan Yadav., et al (2016: 372- 377), Datura metel merupakan species beracun dari family Solanaceae.

Species Physalis angulata (Ceplukan) ditemukan di sepuluh desa. Hal ini karena tanaman ini bisa tumbuh dimana saja, baik tegalan, pinggiran jalan, hutan yang terbuka atau tumbuh secara liar, sehingga banyak ditemukan pada keempat desa tersebut. Ceplukan umumnya tumbuh liar, biasa didapati bercampur dengan herba dan semak lainnya di kebun, tegalan, sawah yang mengering, tepi jalan, tepi hutan dan bagian-bagian hutan yang terbuka disinari terik. Selain itu menurut masyarakat setempat tanaman ini dapat dimanfaatkan sebagai obat penurun demam. Ceplukan bermanfaat sebagai tanaman herbal (obat-obatan). Akar tumbuhan ceplukan digunakan sebagai obat cacing dan penurun demam. Menurut Latifah., dkk (2014), Physalis angulata merupakan tumbuhan liar, berupa semak/perdu yang rendah (biasanya tingginya sampai 1 meter) dan mempunyai umur kurang lebih 1 tahun. Tersebar di tanah tegalan, sawah-sawah kering, serta dapat ditemukan di hutan-hutan jati.

Species Solanum lycopersicum ditemukan di sepuluh Desa. Hal ini disebabkan masyarakat kesepuluh desa tersebut pada umumnya sudah melakukan penyediaan dan pengelolaan tanah yang sesuai karakter tanaman tomat yang mana dilakukan dengan baik pada waktu penanaman tomat. Selain itu dapat menyembuhkan sariawan, menghaluskan kulit, kesehatan mata, dan luka bakar.
Menurut Hariana (2014:2008), Solanum lycopersicum merupakan obat luka bakar, sariawan, dan diabetes.

Species Solanum nigrum hanya ditemukan di keempat Desa yaitu Desa Srikaton, Desa Teral Rejo, Desa Trikoyo, dan Desa Wonorejo. Hal ini karena masyarakat di desa lainnya masih jarang yang membudidayakan tanaman ini karena masyarakat disana tidak menyukai rasa daunnya yang agak langu. Buahnya agak getir dan dijadikan sebagai lalapan mentah. Solanum nigrum tidak sesuai pada tempat tumbuhnya yang mana ditemukan pada lokasi penelitian, dibawah tumbuhan yang lebih besar sehingga tanaman ini tidak terkena langsung sinar matahari atau tumbuh pada kawasan yang kurang terang dan masyarakat sekitar lokasi penelitian juga banyak yang tidak melakukan pengolahan dan perawatan dengan baik. Oleh karena itu tanaman ini banyak yang musnah, sehingga tidak ditemukan pada keenam desa tersebut. Tumbuhan Ranti merupakan tumbuhan terna atau perdu semusim atau tahunan, tumbuhan ini tergantung tempat hidupnya. Tumbuhan ini menyukai kawasan ladang atau kebun yang terang. Menurut Purwaningsih (2016), Solanum nigrum sebagai antikanker, mencegah dan mengurangi peradangan, menurunkan demam (penurun panas), mengurangi rasa sakit, melancarkan sirkulasi darah (mencegah jipertensi), meredakan batuk yang disertai dahak dan melegakan nafas, antibiotik, antimikroba, menghilangkan gatal (Anti-pruritus), dan emiliki aktifitas antiulserogenik yang terhubung dengan lambung, sistem saraf pusat, dan sebagai agen anti-neoplastik. Hal ini juga memiliki peran sebagai sitoprotektif yang melawan kerusakan pada ginjal.

Spesies Solanum tuberosum hanya ditemukan di keempat desa yaitu Desa Dwijaya, Desa Sidoharjo, Desa Widodo, dan Desa Wukirsari. Hal ini karena masyarakat di desa lainnya masih jarang yang membudidayakan tanaman ini karena masyarakat disana kurang tertarik untuk mengembangbiakkan Solanum tuberosum di keenam Desa yang lainnya. Selain itu keempat Desa yaitu Desa Dwijaya, Desa Sidoharjo, Desa Widodo, dan Desa Wukirsari memiliki tanah yang gembur dan basah, serta sedikit mengandung pasir. Menurut Sunarjono (2007) bahwa tumbuhan 
solanaceae secara umum memerlukan tanah yang gembur, sedikit mengandung pasir, dan memerlukan tanah yang beriklim basah.

Species Solanum torvum ditemukan di sepuluh Desa. Hal ini karena takokak banyak digemari oleh masyarakat kesepuluh desa tersebut untuk dijadikan lalap dan di masak. Oleh karena itu, masyarakat setempat membiarkan tanaman ini tumbuh dimana saja, baik tumbuh dipekarangan rumah mereka sendiri, selain itu takokak dapat tumbuh baik dataran rendah maupun dataran tinggi. Menurut Sirait, 2009:12, Solanum torvum dapat mengobati bengkak, batuk kronis, nyeri jantung, hipertensi. Selanjutnya Menurut Hariana, 2008:93, Solanum torvum dapat mencegah mata minus, melancarkan peredaran darah.

Berdasarkan hasil yang didapat pada tabel 2, dari ke-11 species yang ditemukan, terdapat 6 species yang paling banyak ditemukan dari kesepuluh Desa yaitu Capsicum annum, Capsicum frutescens, Physalis angulata, Solanum indicum, Solanum lycopersicum, dan Solanum torvum. Hal ini disebabkan karena tumbuh-tumbuhan ini (Capsicum annum, Capsicum frutescens, Physalis angulata, Solanum indicum, Solanum lycopersicum, dan Solanum torvum), merupakan tanaman yang dibudidayakan masyarakat setempat dan tumbuh liar, khususnya Capsicum annum, Capsicum frutescens, Solanum indicum, dan Solanum lycopersicum selain dijadikan sebagai sayuran juga menambah perekonomian warga setempat. Selain itu tanaman ini juga cocok dengan $\mathrm{pH}$ tanah kesepuluh desa tersebut yaitu 6,2-6,8. Hal ini didukung oleh pendapat Sunarjono (2007) bahwa tumbuhan solanaceae secara umum memerlukan tanah yang gembur, sedikit menggandung pasir, $\mathrm{pH}$ tanahnya 5-6, ditanam di dataran rendah sampai dataran tinggi dengan suhu udara sekitar $20^{\circ} \mathrm{C}$ serta memerlukan tanah yang beriklim basah (curah hujan 1000-2000 mm per tahun). Adapun 2 species yaitu Physalis angulata dan Solanum torvum merupakan tumbuhan liar dan dapat dijumpai dimana-mana terutama ditempat terbuka, seperti di pinggiran jalan, pinggiran sungai, semak-semak, tanah terlantar, dan di antara rerumputan.

Species yang paling sedikit ditemukan dari kesepuluh desa yang dijadikan penelitian adalah
Cestrum nocturnum. Hal ini karena species ini tidak terlalu cocok hidup pada kesepuluh lokasi penelitian, karena secara geografis berada pada daerah dataran rendah (dibawah $1000 \mathrm{~m} \mathrm{dpl}$ ). Species ini hanya ditemukan di pekarangan rumah masyarakat. Secara geografis Cestrum nocturnum tumbuh di dataran tinggi yaitu $1-1.500 \mathrm{~m}$ dpl (Steenis., et al 2008:348).

Dari 10 Desa yang dijadikan lokasi penelitian yaitu Desa Dwijaya, Desa Mataram, Desa Sidoharjo, Desa Srikaton, Desa Tambahasri, Desa Tegal Rejo, Desa Trikoyo, Desa Widodo, Desa Wonorejo, Desa Wukirsari, bahwa Desa Dwijaya yang paling banyak ditemukan dengan jumlah 10 species, sedangkan yang paling sedikit ditemukan adalah Desa Mataram dengan jumlah 7 species. Hal ini karena Desa Dwijaya memiliki luas wilayah 1074,97 Ha. Adapun luas lahan pemukiman dan fasilitas umum lebih sempit, dibandingkan luas lahan pertanian, perkebunan dan lahan yang belum digarap, dibandingkan sembilan Desa yang lain. Hal ini menyebabkan tumbuhan family Solanaceae banyak terdapat di Desa Dwijaya tersebut, karena pada umumnya pertumbuhan Solanaceae dapat berkembang lebih baik pada daerah pertanian, perkebunan dan juga lahan yang belum digarap serta di pinggir sungai ketupat (Pemerintah Kabupaten Musi Rawas, 2010). Selain itu, banyaknya masyarakat di Desa Dwijaya yang bercocok tanam tumbuhan Solanaceae yang tujuannya untuk menambah perekonomian atau sebagai mata pencaharian mereka, sedangkan Desa Mataram species yang ditemukan paling sedikit bila dibandingkan dengan Desa Dwijaya, Desa Sidoharjo, Desa Srikaton, Desa Tambahasri, Desa Tegal Rejo, Desa Trikoyo, Desa Widodo, Desa Wonorejo dan Desa Wukir Sari. Species yang ditemukan pada Desa Mataram hanya 7 species. Hal ini karena Desa Mataram memiliki luas wilayah 475,94 Ha. Selain itu Desa Mataram memiliki luas lahan pemukiman dan fasilitas umum lebih luas, dibandingkan luas lahan pertanian, perkebunan dan lahan yang belum digarap, dibandingkan dengan Desa Dwijaya, Desa Sidoharjo, Desa Srikaton, Desa Tambahasri, Desa Tegal Rejo, Desa Trikoyo, Desa Widodo, Desa Wonorejo dan Desa Wukir Sari. Hal ini menyebabkan tumbuhan Solanaceae berkurang di Desa Mata- 
ram tersebut, karena pada umumnya pertumbuhan Solanaceae tidak dapat berkembang baik pada daerah pemukiman karena kondisi lingkungan yang kurang mendukung. Selain itu banyaknya masyarakat di sekitar lokasi penelitian yang bercocok tanam satu tanaman saja misalnya daerah persawahan, hanya tanaman padi saja yang mereka kembangkan tidak untuk tumbuhan yang lain. Selanjutnya Suhu di Desa Mataram lebih tinggi yaitu $28-33^{\circ} \mathrm{C}$ di bandingkan dengan Suhu di kesembilan Desa lainnya. Hal ini menyebabkan tumbuhan Solanaceae berkurang di Desa Mataram tersebut, karena pada umumnya pertumbuhan Solanaceae tidak dapat tumbuh pada daerah yang faktor abiotik yaitu suhu yang tinggi sehingga kurang mendukung untuk tumbuhnya tumbuhan family Solanaceae di Desa Mataram. Hal ini didukung oleh pendapat Sunarjono (2007) suhu udara yang terlalu tinggi dapat menimbulkan kematian pada tanaman.

\section{KESIMPULAN}

Berdasarkan hasil penelitian tentang identifikasi famili solanaceae yang terdapat di Kecamatan Tugumulyo Kabupaten Musi Rawas, maka dapat disimpulkan yaitu jenis tumbuhan famili Solanaceae yang terdapat di Kecamatan Tugumulyo Kabupaten Musi Rawas terdiri dari 5 genus dan 11 species yaitu Genus Solanum diperoleh 6 species: Solanum indicum (Terung peuheur), Solanum lycopersicum (Tomat), Solanum melongena (Terung), Solanum nigrum (Leunca) dan Solanum torvum (Takokak), Solanum tuberosum (Kentang). Kemudian genus Capsicum diperoleh 2 species: Capsicum annum (Cabe merah) dan Capsicum frutescens (Cabe rawit), genus Datura diperoleh 1 species: Datura metel (Kecubung), genus Brugmansia diperoleh 1 species: Cestrum nocturnum (Harum Dalu), dan genus Physalis diperoleh 1 species: Physalis angulata (Ceplukan).

\section{DAFTAR PUSTAKA}

Faiha, A. (2015). Apotek Hidup. Jakarta: Genis Publisher.

Hariana, A. (2008). Tumbuhan Obat dan Khasiatnya Seri 3. Jakarta: Penebar Swadaya.

Knapp, S., dkk. (2004). Solanaceae - a model for linking genomics with biodiversity.
(Online). http://onlinelibrary.wiley.com/ doi/10.1002/cfg.393/full (Diakses tanggal 15 April 2016).

Kurniawan, F. (2017). Manfaat Besar Kentang bagi Kesehatan dan Kecantikan Alami. (Online). http://fredikurniawan.com/man faat-besar-kentang/ (Diakses tanggal 27 Desember 2017).

Latifah, N., dkk. (2014). Ciplukan (Physalis angulata L.). (Online). http://ccrc.farmasi. ugm.ac.id/?page_id=193 (Diakses tanggal 15 April 2016).

Pemerintah Kabupaten Musi Rawas (Pemkab Mura). (2010). Rencana Pembangunan Jangka Panjang Kabupaten Musi Rawas Tahun 2005-2025. (Online), (http://bap peda.musirawaskab.go.id), diakses 07 Desember 2016.

Permadi, A. (2006). Tanaman Obat Pelancar Air Seni. Jakarta. Penebar Swadaya.

Purwanigsih, D. (2016). Manfaat Leunca untuk Kesehatan. (Online). http://www.1000 macammanfaat.com/2016/02/manfaatleunca-untuk-kesehatan.html (Diakses tanggal 27 Desember 2017).

Putra, W.S. (2016). Kitab Herbal Nusantara: Aneka Resep dan Ramuan Tanaman Obat untuk Berbagai Gangguan Kesehatan. Yogyakarta: Katahati.

Rediana, A. (2016). Kandungan dan Manfaat Terong Untuk Kesehatan Tubuh. (Online). https://www.aryanto.id/artikel/id/315/kan dungan-dan-manfaat-terong-untuk-kesehatan-tubuh (Diakses tanggal 27 Desember 2017).

Santos, M.M., Vieira-da-Motta, O., Vieira, I.J., Braz-Filho,R., Gonçalves,P.S., Maria, E.J., Terra, W.S., Rodrigues, R., Souza, C.L. (2007). Antibacterial activity of Capsicum annum extract and synthetic capsaisinoids derivates against $\mathrm{S}$ treptococcus mutans. J Nat Mes, 66(2), 354-356.

Setshogo, M.P. (2015). A Review of Some Medicinal and or Hallucinogenic Solanaceous Plants of Botswana: The Genus Datura L. International Journal of Medicinal Plants and Natural Products (IJMPNP), 1(2), 1523. 
Sirait, N. (2009). Terong Cepokak (Solanum torvum) Herba yang berkhasiat sebagai Obat. Warta Penelitian dan Pengembangan Tanaman Industri. 15(3), 10-12.

Sotyati. (2016). Arum Dalu, "Ratu Malam” yang Masih Dianggap Gulma. (Online). http://www.satuharapan.com/readdetail/read/arum-dalu-ratu-malam-yangmasih-dianggap-gulma (Diakses tanggal 27 Desember 2017).

Soumya, S.L and Bindu, R Nair. (2012). Antifungal efficacy of Capsicum frutescens L. extract against some prevalent fungal strain associates with graoundnut storeage. Journal of Agricultural Technology, 8(2), 739-750.

Steenis, V., et al. (2008). Flora. Jakarta: Pradnya Paramita.

Sugiyono. (2012). Metode Penelitian Kuantitatif, Kualitatif, dan $R \& D$. (pp. 219). Bandung: Alfabeta.

Sumpena, U. (2013). Penetapan kadar Capsaicin Beberapa Jenis Cabe (Capsicum sp) di Indonesia. Jurnal Ilmu Pertanian, 9(2), 916.

Sunarjono, H. (2007). Bertanam 30 Jenis Sayur. Jakarta: Penebar Swadaya.

Suyoga., dkk. (2016). Preferensi Makan Kumbang Koksi (Epilachna admirabilis) pada beberapa Tanaman Sayuran Famili Solanaceae. Jurnal Simbiosis IV (1): 19-21.

Tjitrosoepomo, G. (2010). Taksonomi Tumbuhan Obat-obatan. Yogyakarta: Gadjah Mada University Press.

Tjitrosoepomo, G. (2009). Taksonomi umum. Yogyakarta: Gadjah Mada University Press.

Tjitrosoepomo, G. (2007). Taksonomi tumbuhan (Spermatophyta). (pp. 353). Yogyakarta: Gadjah Mada University Press.

Tundis, R., Loizzo, M.R., Menichini, F., Bonesi, M., Conforti, F., Statti, G., De Luca, D., De Cindio, B., Menichini, F. (2011). Comparative study on the chemical composition, antioxidant properties and hypoglycaemic activities of two Capsicum annum I. cultivars (Acuminatum small and Cerasiferum). J Plant Foods for Human Nutrition, 66(3), 261 -269.

Yadav, R., Rathi, M., Pednekar, A., and Rewachandani, Y. (2016). A Detailed Review on Solanaceae Family. European Journal of Pharmaceutical and Medical Research, 3(1), 369-378.

Yusuf, M. (2014). Metode Penelitian Kuantitatif, Kualitatif \& Penelitian Gabungan. (pp. 377). Jakarta: Kencana Praneda Media Group 
